\title{
Growth response and physiological activities of the Nile tilapia (Oreochromis niloticus) fed basal diets supplemented with ginger (Zingiber officinale) as natural growth promoters
}

\author{
Raky F. Attalla \\ National Institute of Oceanography and Fisheries, Cairo, Egypt. \\ E-mail rakyniof@yahoo.com
}

\begin{abstract}
A $\mathrm{n}$ experiment was conducted to evaluate the effect of two forms of Adehydrated natural antioxidants rhizomes extracts ginger (Zingiber officinale) on growth performance feed utilization and hematological parameters of Oreochromis niloticus fingerlings. Four treatments were applied, two forms of ginger (powder and oil extract), and their mixtures (1:1) of each form, in addition to control group were fed basal diets without supplements of herbs. The experiment was conducted using cement ponds divided into four equal compartments each was stocked with 40 fingerlings oF Nile tilapia with an average initial body weight of $17.1 \pm 1.2 \mathrm{~g}$, and body length $10.0 \pm 0.7 \mathrm{~cm}$. The experiment lasted for 12 weeks. Generally, growth performance, feed utilization ratios were improved for Nile tilapia (Oreochromis niloticus), fed on diets with the two forms of the feed supplements compared to fish fed on the control diet All growth parameters in all supplemented groups increased significantly $(\mathrm{P}<0.05)$ as compared to the control group, especially for the fish fed on the mixture, with the highest survival rate. Incorporation of ginger extract improved the antioxidant attributes and reduced quality degradation of test diets during storage at ambient conditions. In terms of liver and blood measurements, alkaline phosphatase (ALP), aspartate aminotransferase (AST) and alanine aminotransferase (ALT) activities, these parameters decreased significantly $(\mathrm{P}<0.05)$ for fish fed on all treated groups with ginger. Plasma total protein, albumin and globulins of fish fed on the experimental diets significantly increased $(\mathrm{P}<0.05)$ for those fed on the ginger, while blood glucose, triglycerides and cholesterol values were significantly decreased $(\mathrm{P}<0.05)$ in the same treated groups as compared to the control one. These results revealed that the feeding with a mixture of ginger (powder and oil extract), can promote growth rate, decrease mortality rate and improve the physiological activities in reared fish, and can be potentially used as good sources of antioxidants.
\end{abstract}

Key words: Growth, physiological activities, Oreochromis niloticus, Zingiber officinale

\section{INTRODUCTION}

In recent years natural herbs have gained much attention and therefore the production of these compounds and the identification of new natural sources 
of bioactive and antioxidant compounds have gained scientific and industrial important (Kan et al., 2008). Natural antioxidants have recently gained increased interest because of the belief that natural food ingredients are better and safer than synthetic ones (Pokorny, 1991). When natural antioxidants are compared with synthetic ones, they are readily acceptable by consumers in many different countries because natural antioxidants are considered to be safer. This herb has been found to possess antioxidative, antibrowning, antimicrobial and preservative properties useful in food industries (Adegoke and Skura, 1994). Family Zingiberacae seeds, pods, leaves, rhizomes and flowers are used in traditional medicine and as spices in Cameron and southern Ethiopia. Every $\mathrm{g} / 100 \mathrm{~g}$ dry weight contains thiamin (0.02 microgram); riboflavin (0.04 microgram); niacin (0.09 microgram); ascorbic acid.( (3.49 mg/100 g DW) condensed tannin content (1.18 mg/g DW) (Eyob et al., 2008;). The genus Zingiber belongs to the economically and medicinally important family Zingiberaceae. Ginger (Zingiber officinale) is a spice and widely used for medicinal, dietary and spiritual purposes (Sob et al., 2007; Jazet et al., 2008). There are, however, some reports concerned with antimicrobial and antioxidant activities from related genus, Aframomum giganteum (Huguette et al., 2004), Aframomum melegueta (Adegoke et al., 2003) and Aframomum danielli (Adegoke and Gopalakrishna, 1998) Aframomum corrorima (Eyob et al., 2008).

Ginger (Zingiber officinale) is now exciting considerable interest for its potential to treat many aspects of cardiovascular disease, also ginger shows considerable anti-inflammatory, antioxidant, anti-platelet, hypotensive and hypolipidemic effect in vitro and animal studies. Human trials have been few and generally used a low dose with inconclusive results; however dosages of $5 \mathrm{~g}$ or more demonstrated significant anti-platelet activity (Nicoll and Henein, 2009).

Currently, there is a renewed interest in ginger, and several scientific investigations aimed at isolation and identification of active constituents of ginger, scientific verification of its pharmacological actions and of its constituents, and verification of the basis of the use of ginger in some of several diseases and a strong anti-oxidant substance and may either mitigate or prevent generation of free radicals (Ivan and Ross, 2005: Ali et al., 2008).

Ginger showed moderate activity against gram-positive bacteria and $S$. cerevisiae in culture media. Aqueous and acetone ginger extracts significantly decreased fungal growth in inoculated and naturally-infected strawberries. These extracts reduced all fungal growth by an average of $55 \%$ over the conventional fruit-product preservative, sodium benzoate. This opens a new possibility of using ginger extracts as herb preservatives. (Karamjit, 2007).

Lipid peroxidation is a major cause of food quality deterioration during processing and storage. Products of lipid peroxidation have been associated with carcinogenesis, mutagenesis, ageing, cytotoxicity and atherosclerosis .Oxidation of lipid initiates other changes in food, which affects its nutritional quality. From 
the nutritional standpoint, hydroperoxides reduce the essential fatty acid content, destroy carotene, vitamin A and tocopherols, and also lower the nutritional value of protein. Antioxidants are known to protect food quality by delaying or inhibiting free radical oxidation of fats and oils and the resulting off-odour and flavour (Chang et al., 1977; Economou et al., 1991; Adegoke et al., 2000; Adegoke et al., 2004; Bhandari et al., 2005; Khanam et al., 2006; Kerdchoechuen, 2007).

Some have been shown to possess useful biological activities of ginger belonging mainly to phenolic, flavonoid, carotenoid, terpenoid and triterpene. Extracts and metabolites of this plant, from rhizomes possess useful pharmacological activities. Ginger (Zingiber officinale) is mainly known for its antimicrobial properties and also has been used extensively as a hypoglycaemic agent. Many pharmacological studies have demonstrated the ability of this plant to exhibit antioxidant, hepatoprotection, antimicrobial, antigenotoxic, antiplasmodial, cytotoxic, antispasmodic, cardioactive, anticough, antidiabetic, antiinflamatory and antinociceptive activities, supporting its traditional uses.(Leung et al., 1996; Ivan and Ross, 2005), Zingiber officinale is used as a body stimulant, energetic, tonic and aphrodisiac (Oliveira et al., 2005).

The major components of dried seed and pod oils of ginger (Zingiber officinale) were found to be 1,8-cineole (44.3\%) and (E)-nerolidol (17.2\%), respectively, the average moisture contents were $80.53 \%$ in leaves, $90.30 \%$ in rhizomes, $88.00 \%$ in pods and $14.19 \%$ in seeds when analyzed from fresh samples (Ivan and Ross, 2005).The same author added that the essential oils yield of leaves, rhizomes, pods and seeds were $0.46 \%, 0.69 \%, 0.83 \%$ and $4.30 \%$ on a $\mathrm{w} / \mathrm{w}$ dry basis, respectively and $0.09=\%, 0.15 \%$ and $3.57 \%$ on a $\mathrm{w} / \mathrm{w}$ wet basis, respectively. The oil yield from seeds was remarkably higher compared with other parts of ginger The level of seed extracts (4.30\%), total ascorbic acid and condensed tannin contents of common fresh fruit $(3.49 \mathrm{mg} / 100 \mathrm{~g} \mathrm{DW})$ and $(1.18 \mathrm{mg} / \mathrm{g}$ DW) respectively.

The essential oil of ginger is obtained by steam distillation or hydrodistillation of the dried rhizome was found to contain 1,8-cineole, terpinyl acetate and nerolidol (Abegaz et al., 1994). The same author concluded that, the main constituent of the essential oil (3.5\%) was identified as: $38 \% 1,8$-cineol; $10.5 \%$ limonène; $5.5 \%$ b-pinène; $12 \%$ sabinène; $4 \%$ terpinène- $4-\mathrm{ol} ; 5 \%$ géraniol; $4 \% \mathrm{p}$-cymène; $3 \%$ de chaque, a-pinene, a-terpineol, g-terpinène; $12.5 \%$ nérolidol; $2 \%$ b-ryophyllene; $1 \%$ oxyde de caryophylene.

Five compounds were isolated from the chloroform-soluble fraction of the methanolic extract of the dried rhizomes of ginger (Zingiber officinale) through repeated column chromatography. Their chemical structures were elucidated as 4-, 6-, 8, and 10-gingerols, and 6-shogaol using spectroscopic analysis. Among the five isolated compounds, 6-shogaol exhibited the most potent cytotoxicity against human. 6-shogaol inhibited proliferation of the transgenic mouse ovarian cancer cell lines, (Kim et al., 2008). 
Three new diarylheptanoids and one new monoterpenoid were isolated from the rhizomes of ginger (Zingiber officinale). They were deduced as 5-[4hydroxy-6-(4 hydrox phenethyl) tetrahydro-2 H-pyran-2-yl]-3-methoxybenzene1,2-diol (1), sodium (E)-7-hydroxy-1,7-bis (4 Hydroxyl phenyl) hept-5-ene-3 Ssulfonate (2), sodium (E)-7-hydroxy-1,7-bis(4-hydroxyphenyl) hept-5-ene-3 Rsulfonate (3), and hydroxycineole-10-O-beta-D-glucopyranoside (4), respectively. These compounds were demonstrated to exhibit potent protection against lipid peroxidation in mouse liver microsomes exposed to oxidative conditions. These compounds were subsequently tested on primary cultures of rat hepatocytes exposed to oxidative damage, and definitive cytoprotective actions were found. (Tao et al., 2008).

The aim of this paper is to estimate the effect of oil and powder forms of ginger as antioxidants and preservatives on diets of tilapia, to review the stabilization of relatively unstable edible diets with natural antioxidants also to investigate new sources of natural antioxidants with its multiple biological activities on fish growth response. The present study is the first pilot study to assess the potential of ginger (Zingiber officinale) as natural additive in fish diets.

\section{MATERIALS AND METHODS}

The spice ginger (Zingiber officinale) powder and fresh oil was obtained from the local market produced by Cap Pharm for extracting oils, herbs and Cosmetics, El Obour City, Cairo, Egypt.

\section{2-1 Experimental design}

This study was conducted in a $40 \mathrm{~m}^{3}$ concrete tank (of the Barrage Fish Farm which belongs to NIOF, Cairo, Egypt), divided by using plastic nets into 4 parts each of a total volume of $10-\mathrm{m}^{3}$.The four parts represented 4 dietary treatments i.e. the control un supplemented diet, the diet supplemented with $2 \%$ ginger powder (D1), the diet supplemented with ginger oil $0.5 \%$ (D2) and the diet supplemented with the mixture of ginger powder and oil (1:1) at $1.25 \%$ (D3). Each part of the pond was stocked with mixed sex Nile tilapia with an initial weight $17.1 \pm 1.2 \mathrm{~g}$, and body length $10.0 \pm 0.7 \mathrm{~cm}$. The experiment lasted 12 weeks and the experimental fish were fed on the diet at a rate of $3 \%$ of fish biomass 6 days /week. The fish were obtained from a commercial fish farm and were acclimated 14 days in one of $\left(10-\mathrm{m}^{2}\right)$ before starting the feeding trial. The experimental diets were formulated to contain almost $28.5 \pm 0.15 \%$ crude protein.

\section{2-2 Experimental diets}

The composition of the test diets is presented in Table (1). Proximate compositions of the ginger (Zingiber officinale) powder are shown in Table (2) and. Diet composition was determined at the start and at the end of the trails using standard procedures (AOAC, 1995) (Table.3). 
Table 1, Composition of the experimental diets (g. /100g dry matter).

\begin{tabular}{|l|c|c|c|c|}
\hline Feed Ingredients: & $\begin{array}{c}\text { Control } \\
\text { Additives Free }\end{array}$ & $\begin{array}{c}\text { Diet 1 } \\
\text { Powder }\end{array}$ & $\begin{array}{c}\text { Diet 2 } \\
\text { Oils }\end{array}$ & $\begin{array}{c}\text { Diet 3 } \\
\text { Mixture }\end{array}$ \\
\hline Fish meal $(62 \% \mathrm{CP})$. & 15 & 15 & 15 & 15 \\
\hline Corn gluten $(60 \% \mathrm{CP})$. & 15 & 15 & 15 & 15 \\
\hline Soy bean meal (44\%CP). & 18 & 18 & 18 & 18 \\
\hline Wheat bran. & 16 & 16 & 16 & 16 \\
\hline Yellow corn. & 32 & 30 & 31.5 & 30.75 \\
\hline Soy oil. & 2 & 2 & 2 & 2 \\
\hline Vit. \& Min. Mix. & & 2 & 2 & 2 \\
\hline ginger powder. & 2 & 2.0 & - & - \\
\hline ginger oils. & - & - & 0.5 & - \\
\hline Mixture ${ }^{2}$. & - & - & - & 1.25 \\
\hline TOTAL & 100 & 100 & 100 & 100 \\
\hline
\end{tabular}

1-Commercial feed contained a vitamin and mineral premix with the following composition/kg product: folic acid $250 \mathrm{mg}$, pantothenic acid $5000 \mathrm{mg}$, biotin $125 \mathrm{mg}$, copper $2000 \mathrm{mg}$, coline $25000 \mathrm{mg}$, iron $13820 \mathrm{mg}$, iodine $100 \mathrm{mg}$, magnesium $3750 \mathrm{mg}$, niacin $5000 \mathrm{mg}$, selenium $75 \mathrm{mg}$, vitamin $1000000 \mathrm{UI}$, vitamin B1 1250 $\mathrm{mg}$, vitamin B12 $3750 \mathrm{mg}$, vitamin B2 $2500 \mathrm{mg}$, vitamin B6 $1875 \mathrm{mg}$, vitamin C $42000 \mathrm{mg}$, vitamin D3 500000 UI, vitamin E 20000 UI, vitamin K3 500mg, zinc $17500 \mathrm{mg}$.

2-Mixture of the two forms of the ginger powder and oils (1:1).

Table 2: Nutrient composition ginger (Zingiber officinale) antioxidant powder (g/100g dry weight)

\begin{tabular}{|l|c|}
\hline Items & Chemical composition \\
\hline Crude protein \% & 9.68 \\
\hline Crude fiber $\%$ & 2.82 \\
\hline Ether extract $\%$ & 4.17 \\
\hline Ash $\%{ }^{1} \quad \%$ & 10.84 \\
\hline Moisture $\quad 63.48$ \\
\hline Nitrogen free extract(NFE) ${ }^{2}$ & 354.27 \\
\hline Gross energy Kcal/ $100 \mathrm{~g}^{3}$ & 27.32 \\
\hline Protein $/$ Energy ratio & 0.43 \\
\hline Lipid/ protein ratio & \\
\hline
\end{tabular}

1- Ash composition (g/100g) of ginger (Zingiber officinale): Calcium. (21.9 mg); Phosphor. (137 $\mathrm{mg})$; Iron. $\quad$ (0.3 microgram).

2- Nitrogen-free extract, determined by difference.

3- Gross energy content of the diets was calculated by using the factors of $5.65 \mathrm{Kcal} / \mathrm{g}$ proteins,

$9.45 \mathrm{kcal} / \mathrm{g} \quad$ lipids and $4.10 \mathrm{kcal} / \mathrm{g}$ diet (NRC, 1993)

4- Protein / Energy ratio $=\mathrm{mg}$ protein $/ \mathrm{Kcal}$.

5 -Lipid $/$ Protein ratio $=\mathrm{mg}$ lipid $/ \mathrm{Kcal}$. 


\section{2-3 Evaluation of fish performance}

Fingerlings growth was monitored biweekly and feed ration rate of each treatment was then readjusted accordingly, throughout the experimental period 84 days. The following calculations were conducted for estimation of growth and feed utilization parameters:

1) Average total weight gain $(\mathrm{TWG})=$ mean final body weight - mean initial body weight.

2) Feed conversion ratio $(\mathrm{FCR})=$ Total dry feed consumed $(\mathrm{g}) \div$ total wet weight gained (g).

3) Specific growth rate $(\mathrm{SGR})=[(100 \times \mathrm{Ln}$ fi nal average weight $-\mathrm{Ln}$ initial average weight)/ days]. 4) Daily weight gain DWG.(g/fish/day)=. Average final weight (g) - average initial weight $(\mathrm{g})$ /days

5) Feed efficiency $(\mathrm{FE})=($ Body weight gain $(\mathrm{g}) /$ feed intake $(\mathrm{g})$

$6)$ Protein efficiency ratio $(\mathrm{PER})=$ Wet weight gained $(\mathrm{g}) \div$ Amount of protein consumed (g).

7) Condition factor $(\mathrm{k})=100\left(\mathrm{Wt} / \mathrm{L}^{3}\right)$, where $\mathrm{Wt}$ is fish body weight $(\mathrm{g}), \mathrm{L}$ is total length $(\mathrm{cm})$

8) Hepatosomatic index (HIS, \%) = (Liver weight / body weight) $\times 100$

9) Gonadosomatic index (GSI) = Ovary or testes weight/body weight) $\times 100$

10) Survival rate $=$ No of survive fish/total No. of fish at the beginning $X 100$

11) Protein productive value PPV (\%)Increase in fish body protein $(\mathrm{g}) / \mathrm{crude}$ protein intake $(\mathrm{g}) \times 100$.

12) Intraperitoneal fat ratio IPF (\%) = wet weight of fat $x 100 /$ body weight).

13) Energy retention value ERV $(\%)=($ Energy increase in body Kcal /energy intake, Kcal) x100.

\section{2-4 Biochemical Analysis}

At the start and the end of the trails, proximate composition of fish flesh and liver were recorded at (Tables. 5 and 6). An initial sample of 5 fish per aquarium were killed prior to the start of the experiment and a final sample of 10 fish per aquarium were treated similarly and the flesh was subjected to proximate analysis, except crude fiber (AOAC, 1995).Livers were taken at the end of the experiment and weighed, and homogenized with $5 \mathrm{ml}$. distilled water. Hepatic glycogen was determined by using the method by Handel (1965), hepatic lipids (Zollner and Kirsch, 1962) and total hepatic protein according to the method described by (Gornall et al., 1949).

Blood was collected using heparinized syringes from caudal vein of the experimental fish at the end of the experiment. Blood was centrifuged at 3000rpm for 15 minutes. Samples were subjected to determination of plasma total protein (PTP) (Armstrong and Carr, 1964) and plasma albumin (PA) (Doumas, et al., 1977). Aspartate aminotransferase (AST) and Alanine aminotransferase (ALT) were determined according to (Rettman and Frankel, 1975).Triglycerides (STG) and cholesterol (Ch.) was determined according to the method described by (Stein, 1986).Alkaline phosphatase (ALP) activity was 
determined by using the method of Williamson, 2003, while glucose concentration was measured according to Trinder, (1969). Carotene in plasma (PC) was determined by the method of Alexander (1985), by adding $2 \mathrm{ml}$ of ethyl alcohol $95 \%$ to $2 \mathrm{ml}$ plasma followed by $4 \mathrm{ml}$ of petroleum ether and centrifuged at 10,000 rpm for 5 minuets then read at $450 \mathrm{~nm}$.

\section{2-5 Statistical analyses}

Data were analyzed by one way ANOVA to determine significant differences $(\mathrm{P}<0.05)$ among treatment means. All statistical analyses were conduced using the Statistical Analysis System (SAS; 2002, software version 8.2, Cary, NC, USA). Duncan's multiple range test (Duncan, 1955) was used to separate differences between treatment means at the probability level of 5\%.

\section{RESULTS}

Water temperature was recorded twice a day and averaged of about 24.2 $\pm 1.2^{\circ} \mathrm{C}$ and dissolved oxygen average was $5.5 \pm 0.73 \mathrm{mg} / 1$. Other parameters, such as $\mathrm{pH}$, turbidity, alkalinity, and total ammonia concentration, were determined weekly. The average water $\mathrm{pH}$ remained around 6.9; alkalinity around $18 \pm 0.01 \mathrm{mg} / \mathrm{L}$ total ammonia concentration averaged $0.26 \pm 0.03 \mathrm{mg} / \mathrm{L}$ during the experimental period, and all tested water parameters were within the acceptable ranges for Nile tilapia as reported by Boyd (1990).

\section{3-1 Antioxidant effectiveness:}

Concerning the antioxidant effectiveness of studied ginger forms extract on chemical composition of diets, results presented in Table (3) show that, at the start of diets formulation, the control diet as well as the tested diets D1, D2 and D3 had almost similar moisture; crude protein; ether extract; crude fiber; ash; NFE; gross energy; protein to energy and lipid to protein ratios.

After 14 weeks of storage under ambient conditions all diets showed slight increases in moisture contents especially the control diet (ginger free). Also, three supplemented diets revealed slight reduction in protein contents, while protein contents of the control diet were decreased significantly from 28.42 to 27.58 than those supplemented diets with ginger D1, D2 and D3, from (28.57; 28.50.and 28.55) to $28.45 ; 28.36$ and 28.50$)$ respectively. Ether extract of ginger diets (D1, D2 and D3) after 14 weeks of storage were lower than those at the start of diets formulation, in contrast, final contents of lipids of the control diet which was free from ginger were slightly increased. Crude fiber; ash and NFE seemed to be slightly affected. Also, the applied treatments seemed to have minimal effects on gross energy; protein to energy and lipid to protein ratios after the storage period. 
Table 3. Proximate analysis of the experimental diets, at the beginning and the end of the experiment (g./100g dry diet).

\begin{tabular}{|c|c|c|c|c|c|c|c|c|}
\hline \multirow{4}{*}{ Items } & \multicolumn{6}{|c|}{ Chemical composition } & & \\
\hline & \multicolumn{2}{|c|}{ Control } & \multicolumn{2}{|c|}{1} & \multicolumn{2}{|c|}{2} & \multicolumn{2}{|c|}{3} \\
\hline & \multicolumn{2}{|c|}{ storage period } & \multicolumn{2}{|c|}{ storage period } & \multicolumn{2}{|c|}{ Storage period } & \multicolumn{2}{|c|}{ storage period } \\
\hline & At start & Final & $\begin{array}{c}\text { At } \\
\text { start }\end{array}$ & Final & $\begin{array}{c}\text { At } \\
\text { start }\end{array}$ & Final & At start & Final \\
\hline Moisture. & 9.73 & 10.33 & 9.58 & 9.71 & 9.65 & 9.67 & 9.71 & 9.74 \\
\hline Crude protein. & 28.42 & 27.58 & 28.57 & 28.45 & 28.50 & 28.36 & 28.55 & 28.50 \\
\hline $\begin{array}{l}\text { Lipid (Ether } \\
\text { extract). }\end{array}$ & 6.90 & 7.03 & 6.76 & 6.45 & 6.82 & 6.52 & 6.78 & 6.53 \\
\hline Crude fiber. & 5.20 & 5.24 & 5.22 & 5.13 & $5 . .18$ & 5.27 & 5.21 & 5.18 \\
\hline Ash. & 6.70 & 6.78 & 7.14 & 7.30 & 7.10 & 7.17 & 7.03 & 7.04 \\
\hline $\begin{array}{l}\text { Nitrogen free } \\
\text { extract.(NFE) }\end{array}$ & 43.05 & 43.09 & 42.73 & 42.90 & 42.75 & 43.01 & 42.72 & 43.19 \\
\hline $\begin{array}{l}\text { Gross energy Kcal/ } \\
100 \mathrm{~g}^{1}\end{array}$ & 402.28 & 398.93 & 400.5 & 397.59 & 400.76 & 398.18 & 400.57 & 399.82 \\
\hline $\begin{array}{l}\text { Protein /Energy } \\
\text { ratio }^{2}\end{array}$ & 70.65 & 69.13 & 71.34 & 71.56 & 71.11 & 71.22 & 71.27 & 71.28 \\
\hline Lipid/ protein ratio & 24.28 & 26.47 & 23.66 & 22.67 & 23.93 & 22.99 & 23.75 & 22.91 \\
\hline
\end{tabular}

1- Gross energy content of the diets was calculated by using the factors of $5.65 \mathrm{Kcal} / \mathrm{g}$ proteins,

$9.45 \mathrm{kcal} / \mathrm{g} \quad$ lipids and $4.10 \mathrm{kcal} / \mathrm{g}$ diet $(\mathrm{NRC}, 1993)$

2- Protein / Energy ratio $=\mathrm{mg}$ protein $/$ Kcal.

\section{3-2 Growth response and biological parameters:}

The measured growth indices (TWG g/fish, DWG g/fish/day, SGR \% /day and K.) as well as feed utilization ratios FCR and PER and feed efficiency FE, $g$ for the four treatments are shown in Table (4). Results revealed that the basal diets supplemented with the ginger significantly improved all the growth measurements, and the fingerlings groups which fed the mixture of the two forms of the ginger had positively affected $(p<0.05)$ the growth response, the nutritional parameters and biological indices (liver and gut indices). However, both ginger forms and their mixture promoted a higher final weight $(81.53$, -84.92) g., and DWG. $(0.78-0.82) \mathrm{g} /$ fish/day, of the fingerlings $(\mathrm{p}<0.05)$ when compared to control group, (74.15) and (0.0.69) g., respectively.

On the other hand, there were no significant differences in the growth response among fish groups fed on diets with ginger. The amounts of dry feed intake FI (g/fish/day) were insignificantly different in fish fed supplemented diets with ginger. Results of in Table (4) show that, FCR decreased significantly $(\mathrm{P}<0.05) 1.55,1.50$ and 1.49 in $O$. niloticus fed on the ginger powder, oil, and mixture diets as compared to the control group (1.74), in contrast PER values increased significantly $(\mathrm{P}<0.05)$ in different treatment groups fed on ginger diets and ranged from (2.26 - 2.37) as compared to the control group (2.01).The same trend was observed feed efficiency (FE) which increased in ginger groups. Also there were no significant differences in the hepatosomatic or gut indices between treated groups and the control one. On the other hand, the gonad indices for male or female tilapia fingerlings improved significantly in fish fed on the ginger 
supplemented diets as compared to the control groups. The best PPV and ERV results observed with ginger supplemented diets which suggested that addition of ginger significantly $(\mathrm{P}<0.05)$ improved protein utilization in commercial diets of tilapia, Moreover Intraperitoneal fat ratio IPF (\%) values decreased significantly $(\mathrm{P}<0.05)$ with the ginger supplemented diets, the best value was recorded for fish fed with the mixture, ginger oils and the powder $(24.39,24.73$, and $25.10, \%$ for D1; D2 and D3 respectively) as compared to control one $(30.64, \%)$.

Table 4; Growth Performance and feed utilization and biological measurements of Oreochromis niloticus fingerlings fed the experimental diets. (Means \pm SE).

\begin{tabular}{|l|c|c|c|c|}
\hline Items & $\begin{array}{c}\text { Control } \\
\text { Additives Free }\end{array}$ & $\begin{array}{c}\text { Diet 1 } \\
\text { powder }\end{array}$ & $\begin{array}{c}\text { Diet 2 } \\
\text { Oils }\end{array}$ & $\begin{array}{c}\text { Diet 3 } \\
\text { Mixture }\end{array}$ \\
\hline Initial body weight (g). & $17.03 \pm 1.2^{\mathrm{a}}$ & $17.10 \pm 1.2^{\mathrm{a}}$ & $17.21 \pm 1.2^{\mathrm{a}}$ & $17.15 \pm 1.2^{\mathrm{a}}$ \\
\hline Final body weight (g). & $74.15 \pm 1.23^{\mathrm{cd}}$ & $81.53 \pm 1.63^{\mathrm{b}}$ & $84.32 \pm 1.14^{\mathrm{ab}}$ & $84.92 \pm 2.12^{\mathrm{a}}$ \\
\hline Initial body Length(cm) & $10.0 \pm 0.8^{\mathrm{a}}$ & $10.0 \pm 0.7^{\mathrm{a}}$ & $9.9 \pm 1.0^{\mathrm{a}}$ & $10.02 \pm 0.7^{\mathrm{a}}$ \\
\hline Final body length(cm). & $16.34 \pm 0.2^{\mathrm{a}}$ & $16.43 \pm 0.2^{\mathrm{a}}$ & $16.39 \pm 0.3^{\mathrm{a}}$ & $16.32 \pm 0.1^{\mathrm{a}}$ \\
\hline Total weight gain (g). & $57.15 \pm 1.22^{\mathrm{d}}$ & $64.43 \pm 1.45^{\mathrm{b}}$ & $67.11 \pm 1.35^{\mathrm{a}}$ & $67.77 \pm 1.40^{\mathrm{a}}$ \\
\hline C.F (K). & $1.70^{\mathrm{c}}$ & $1.84^{\mathrm{b}}$ & $1.92^{\mathrm{a}}$ & $1.95^{\mathrm{a}}$ \\
\hline SGR (\%) & $1.77 \pm 0.05^{\mathrm{cd}}$ & $1.88 \pm 0.1^{\mathrm{b}}$ & $1.92 \pm 0.04^{\mathrm{a}}$ & $1.93 \pm 0.08^{\mathrm{a}}$ \\
\hline DWG. g/fish/day & $0.69^{\mathrm{cd}}$ & $0.78^{\mathrm{b}}$ & $0.81^{\mathrm{a}}$ & $0.82^{\mathrm{a}}$ \\
\hline FI (g/fish) & $99.70^{\mathrm{b}}$ & $100.60^{\mathrm{a}}$ & $100.72^{\mathrm{a}}$ & $100.93^{\mathrm{a}}$ \\
\hline DFI.(g/fish/day) & $1.200^{\mathrm{b}}$ & $1.212^{\mathrm{a}}$ & $1.213^{\mathrm{a}}$ & $1.216^{\mathrm{a}}$ \\
\hline FCR (\%) & $1.74^{\mathrm{cd}}$ & $1.55^{\mathrm{b}}$ & $1.50^{\mathrm{a}}$ & $1.49^{\mathrm{a}}$ \\
\hline PER (\%). & $2.01^{\mathrm{cd}}$ & $2.26^{\mathrm{b}}$ & $2.35^{\mathrm{a}}$ & $2.37^{\mathrm{a}}$ \\
\hline FE (g) & $0.57^{\mathrm{cd}}$ & $0.64^{\mathrm{b}}$ & $0.67^{\mathrm{a}}$ & $0.67^{\mathrm{a}}$ \\
\hline IPF (\%) & $30.64^{\mathrm{a}}$ & $25.10^{\mathrm{b}}$ & $24.73^{\mathrm{c}}$ & $24.39^{\mathrm{c}}$ \\
\hline PPV (\%) & $18.33^{\mathrm{cd}}$ & $30.38^{\mathrm{a}}$ & $30.00^{\mathrm{b}}$ & $30.44^{\mathrm{a}}$ \\
\hline ERV (\%) & $94^{\mathrm{cd}}$ & $4.45^{\mathrm{b}}$ & $4.76^{\mathrm{a}}$ & $4.77^{\mathrm{a}}$ \\
\hline Survival rate (\%). & $97.5^{\mathrm{a}}$ & $95^{\mathrm{b}}$ & $100^{\mathrm{a}}$ \\
\hline Hepatic index & $1.33^{\mathrm{cd}}$ & $1.44^{\mathrm{ab}}$ & $1.45^{\mathrm{ab}}$ & $1.48^{\mathrm{a}}$ \\
\hline Gut indices & $4.55^{\mathrm{a}}$ & $4.60^{\mathrm{a}}$ & $4.60^{\mathrm{a}}$ \\
\hline Gonadosomatic index & $4^{\mathrm{a}}$ & $21 f f e r e n t$ \\
\hline
\end{tabular}

a,b,c...Means in the same row having the different superscript are significantly different $(\mathrm{P} \leq 0.05)$.

\section{3-3 Proximate composition:}

Liver and flesh composition records of Oreochromis niloticus fingerlings fed two forms of (Zingiber officinale) for 12 weeks are represented in (Tables 5 and 6).

Protein content in the body and liver of fish was significantly $(\mathrm{P}<0.05)$ higher in the groups fed on diet containing ginger than in other control groups but no significant difference between the ginger treatment groups were detected. 
Contrarily, total lipids content in both fish liver and body decreased $(\mathrm{P}<0.05)$ significantly in all fish groups fed on ginger as compared to control. Ash content was showed significantly $(\mathrm{P}<0.05)$ decreased in fish fed on ginger diets, but $(\mathrm{P}<0.05)$ difference as compared to control were insignificant. Moisture content in fish body was not significantly affected in all treated groups compared to the control group. Fish liver glycogen was higher in the supplemented diets compared the control one.

Table 5: Proximate flesh composition of Oreochromis niloticus fingerlings fed the experimental diets (As DM basis).

\begin{tabular}{|c|c|c|c|c|c|}
\hline \multirow{2}{*}{ Chemical composition } & \multicolumn{5}{|c|}{ Experimental diets } \\
\hline & Initial & control & 1 & 2 & 3 \\
\hline Moisture $\quad(\%)$ & 77.50 & $76.44^{\mathrm{a}}$ & $75.23^{6}$ & $75.60^{6}$ & $75.52^{b}$ \\
\hline Crude protein $(\%)$ & 56.12 & $61.33^{\mathrm{bc}}$ & $64.80^{\mathrm{a}}$ & $64.62^{a}$ & $64.81^{\mathrm{a}}$ \\
\hline Ether extract $(\%)$ & 24.30 & $22.72^{a}$ & $20.54^{b}$ & $20.85^{b}$ & $20.71^{b}$ \\
\hline Ash (\%) & 19.58 & $15.95^{\mathrm{a}}$ & $14.66^{b}$ & $14.53^{b}$ & $14.48^{b}$ \\
\hline Gross energy Kcal/100g ${ }^{5}$ & 513.91 & $530.54^{\mathrm{c}}$ & $532.49^{\mathrm{ab}}$ & $534.00^{\mathrm{a}}$ & $533.93^{\mathrm{a}}$ \\
\hline Lipid / Protein Ratio & 0.43 & $0.37^{\mathrm{a}}$ & $0.32^{\mathrm{b}}$ & $0.32^{b}$ & $0.32^{\mathrm{b}}$ \\
\hline P/E Ratio & 0.109 & $0.116^{\mathrm{b}}$ & $0.122^{\mathrm{a}}$ & $0.121^{\mathrm{a}}$ & $0.121^{\mathrm{a}}$ \\
\hline
\end{tabular}

a,b,c...Means in the same row having the different superscript are significantly different $(\mathrm{P} \leq 0.05)$

Table 6: Liver composition of Oreochromis niloticus fingerlings fed the experimental diets

\begin{tabular}{|c|c|c|c|c|c|}
\hline \multirow{2}{*}{ Liver metabolites } & \multicolumn{5}{|c|}{ Experimental diets } \\
\cline { 2 - 6 } & Initial & control & 1 & 2 & 3 \\
\hline Crude protein (g/100g tissue) & $20.19^{d}$ & $22.04^{b c}$ & $24.22^{a}$ & $24.17^{a}$ & $24.31^{a}$ \\
\hline Total lipids (g/100g tissue) & $12.30^{a}$ & $11.16^{b}$ & $10.23^{c}$ & $10.24^{c}$ & $10.06^{c d}$ \\
\hline Glycogen (g/100g tissue) & $1.9^{c}$ & $2.4^{b}$ & $3.20^{a}$ & $3.27^{a}$ & $3.10^{a}$ \\
\hline
\end{tabular}

a,b,c...Means in the same row having the different superscript are significantly different $(\mathrm{P} \leq 0.05)$.

\section{3-4 Physiological parameters:}

Concerning blood plasma constituents, average of glucose $\mathrm{mg} / \mathrm{dl}$ were found to be $105 ; 84 ; 85$ and $82 \mathrm{mg}$. /dl for the control; D1; D2; and D3 groups respectively (Table 7 ). Results revealed that supplementing Nile tilapia diets with the ginger tested forms decreased significantly $(\mathrm{P}<0.05)$ average plasma glucose compared to the control group and the decrease was more pronounced in D3. On the other hand, plasma total protein in supplemented groups were significantly $(\mathrm{P}<0.05)$ higher than that of the control. The same trend was decreased in plasma albumen; thus ginger supplemented groups had higher plasma albumen than the control group. Results of diet (D3) revealed that the control group recorded the highest $(\mathrm{P}<0.05)$ triglycerides $(69.05 \mathrm{mg} / \mathrm{dl})$ compared to the other ginger groups. The same trend was observed with total 
cholesterol, thus the control unsupplemented group recorded the highest $(\mathrm{P}<0.05)$ value $(135.0 \mathrm{mg} / \mathrm{dl})$ compared to the ginger supplemented groups. Results of the same table show that the control group recorded the highest alkaline phosphates ALP activities $(47.0 \mathrm{u} / \mathrm{l})$ followed in a significant $(\mathrm{P}<0.05)$ decreasing order by the D2; D1; and D3 respectively. Concerning AST and ALT activities in blood results revealed that the control group showed significantly $(\mathrm{P}<0.05)$ higher activities compared with the ginger supplemented groups. Plasma carotene showed significant increase in all ginger supplemented groups compared to the control one (Table 7).

Table 7: Blood parameters of Oreochromis niloticus fingerlings fed on ginger (powder and oil) extracts supplemented diets (Mean + SE).

\begin{tabular}{|c|c|c|c|c|}
\hline \multirow[t]{2}{*}{ Parameters } & \multicolumn{4}{|c|}{ Experimental diets } \\
\hline & Control & 1 & 2 & 3 \\
\hline Glucose. (mg/dl) & $105.0^{\mathrm{a}}$ & $84.0^{\mathrm{bc}}$ & $85.0^{\mathrm{b}}$ & $82.0^{\mathrm{c}}$ \\
\hline PTP $\quad(\mathrm{g} / \mathrm{dl})$ & $3.10^{\mathrm{b}}$ & $3.57^{\mathrm{a}}$ & $3.56^{\mathrm{a}}$ & $3.56^{\mathrm{a}}$ \\
\hline$(\mathrm{g} / \mathrm{dl})$ & $1.72^{\mathrm{c}}$ & $2.16^{\mathrm{a}}$ & $2.07^{b}$ & $2.15^{\mathrm{a}}$ \\
\hline$(\mathrm{g} / \mathrm{dl})$ & $1.68^{\mathrm{c}}$ & $2.06^{b}$ & $2.19^{\mathrm{a}}$ & $2.10^{b}$ \\
\hline$(\mathrm{mg} / \mathrm{dl})$ & $69.05^{\mathrm{a}}$ & $55.40^{b}$ & $56.10^{b}$ & $53.23^{b}$ \\
\hline$(\mathrm{mg} / \mathrm{dl})$ & $135.0^{\mathrm{a}}$ & $118.0^{b}$ & $120.0^{b}$ & $115.0^{\mathrm{c}}$ \\
\hline$(\mathrm{U} / \mathrm{L})$ & $47.0^{\mathrm{a}}$ & $38.28^{\mathrm{c}}$ & $39.06^{b}$ & $35.90^{d}$ \\
\hline$(\mathrm{U} / \mathrm{L})$ & $121.0^{\mathrm{a}}$ & $86.5^{c}$ & $91^{\mathrm{b}}$ & $90.0^{b}$ \\
\hline (U/L) & $43.0^{\mathrm{a}}$ & $36.0^{b}$ & $33^{c}$ & $35.9^{b}$ \\
\hline$(\mathrm{mg} / 100 \mathrm{ml})$ & $5.22^{\mathrm{cd}}$ & $6.14^{\mathrm{a}}$ & $6.03^{b}$ & $6.16^{\mathrm{a}}$ \\
\hline
\end{tabular}

$a, b, c . .$. Means in the same row having the different superscript are significantly different $(\mathrm{P} \leq 0.05)$

* Plasma total globulins $(\mathrm{PG})(\mathrm{g} / \mathrm{dl})=$ plasma total protein- plasma albumin.

\section{DISCUSSION}

A high oxidative stability of lipids is very important for fish nutrition and the consumer's health and it is also economically important. Ginger (Zingiber officinale) antioxidant extract reduced the oxidation rate and lipid contents in treated diets. On the other hand, lipid content increased in the untreated (control) diets during the experimental storage period. The lipid contents decreased with supplementation of ginger antioxidant extract in test diets. Incorporation of ginger antioxidant extract improved the antioxidant attributes and reduced quality degradation of test diets during storage at ambient conditions $\left(30^{\circ} \mathrm{C}\right)$ for 14 weeks. The present results are in agreements with those recorded by Adegoke et al. (2004) who found that Aframomum danielli antioxidant extract reduced the peroxide value and free fatty acid contents in treated roasted peanuts.

The result obtained in this work showed that ginger antioxidant extract may increased the storage period, and also, decreased the rate of peroxide formation in the treated diets during storage. These results agree with those of Economou et al. (1991) who found that the antioxidant effectiveness of ginger extract on storage time of the test diets increased with the addition of the ginger. Spices 
containing high phenolics provide a source of dietary anti-oxidants in addition to imparting flavor to the food and possess potential health benefits by inhibiting lipid peroxidation (Nedyalka and Emma 2001; Odukoya et al., 2005)

Antioxidant effectiveness of $200 \mathrm{mg} / \mathrm{kg}$ ginge powder; 0.5 oils and 1.25 their mixture on test diets after 98 days was showing that ginger was effective at all forms, on the chemical composition contents of the test diets extended, up to 14 weeks of storage. Mixture of ginger powder and oils extract in the test diets was most effective. Crude protein and ash increased significantly in diets containing the two forms of ginger, while total lipid content decreased significantly with the same forms of ginger. These results partially agree with those mentioned by Adegoke et al. (2000) who found that the antioxidant effectiveness of $70.7 \%$ for $200 \mathrm{ppm}$ of $A$. danielli extract in soybean oil. Antioxidant effectiveness is a measure of antioxidant activity. The decrease in the rate of formation of peroxide can be used as a measurement of the antioxidant activity of extract, generally, rate of peroxidation in the oils decreased with increase in concentration of extracts (Chang et al., 1977). This may be attributed to the action of the antioxidant, which probably broke the free radical chain reaction, thus increasing the induction period, as well as decreasing the rate of peroxide formation. According to Coulter (1988) and Giese (1996) antioxidants do not completely prevent oxidation, but only increase its induction period. These data agree with those reported by (Metwally, 2009) who stated that, antioxidants inhibit or interfere with free radical formation based on their phenolic structure.

The mechanisms of lipid peroxidation and their effect on food quality have been extensively reviewed, and mentioned by Natarajan et al. (2006) who evaluate the antioxidant property of individual ingredients in a spice ginger against the free radical azinobis-(3 ethylbenzothiazoline-6-sulphonic acid). Rats were given feed mixed with ginger for 3 weeks ( $4 \mathrm{~g} / \mathrm{kg}$ of feed). Rats with ginger pretreatment showed significantly lower levels of free radicals, lipid peroxidation and protein carbonyls along with significantly higher levels of antioxidants when compared with rats without ginger (Zingiber officinale) pretreatment. These results reveal that ginger exerts a promising antioxidant potential against free radical induced oxidative damage.

Ahmed et al. (2000) reported thatGinger (Z. officinale) $1 \% \quad \mathrm{w} / \mathrm{w}$ significantly lowered lipid peroxidation by maintaining the activities of the antioxidant enzymes--superoxide dismutase, catalase and glutathione peroxidase in rats. The blood glutathione content was significantly increased in ginger fed rats. Similar effects were also observed after natural antioxidant ascorbic acid $(100 \mathrm{mg} / \mathrm{kg}$, body wt) treatment. The results indicate that ginger is comparatively as effective as ascorbic acid as an antioxidant. He added that the lipid lowering and antioxidant potential of ethanolic extract of ginger (Zingiber officinale) was evaluated in streptozotocin (STZ)-induced diabetes in rats. Ethanolic extract of Zingiber officinale $(200 \mathrm{mg} / \mathrm{kg})$ fed orally for 20 days 
produced significant antihyperglycaemic effect in diabetic rats. Further, the extract treatment also lowered serum total cholesterol, triglycerides and increased the HDL-cholesterol levels when compared with pathogenic diabetic rats. The results indicate that ethanolic extract of Zingiber officinale (Roscoe) can protect the tissues from lipid peroxidation. The extract also exhibit significant lipid lowering activity in diabetic rats (Bhandari et al., 2005). These results agree with those of Jazet et al.(2008) who found that powdered rhizome of ginger in both culture at a concentration $2 \mathrm{mg} / \mathrm{L}$, was active on Lactobacillus plantarum On the other hand, antibacterial effects of volatile components of all extracts of essential oil obtained from five Zingiberaceae species (zingiberene, turmerone, methyl chavicol, and gamma-terpinene), could inhibit growth with the highest efficiency against three positive strains of bacteria (S. aureus, B. cereus and L. monocytogenes), with a minimum concentration of $6.25 \mathrm{mg} / \mathrm{mL}$ (Kerdchoechuen , 2007)

Treatment with $250 \mathrm{mg} / \mathrm{kg}$ of methanol and ethyl acetate extracts of Zingiber officinale for 8 weeks produces significant reduction in body weight, glucose, and insulin and lipid levels as compared to obese control mice. The reduction in elevated glucose along with elevated insulin levels indicates that the treatment with $Z$. officinale improves insulin sensitivity (Goyal et al., 2006).These findings are completely agree with the present results, except the results of the fish body weight which increased in the present study because of ginger may be acts as a good appetizer and growth promoter in the supplemented diet and led to a significant increase in final body weight of Nile tilapia fingerlings.

The present data demonstrated that the final weight, weight gain and SGR increased significantly in all treated groups fed on ginger and the highest growth performance was observed in fish groups fed on ginger containing diets. These results partially agree with those mentioned by (Abou-Zeid 2002) who obtained the highest growth performance in O. niloticus with $2.5 \%$ garlic $/ \mathrm{kg}$ diet. The same author added that garlic supplementation positively affected $O$. niloticus biomass and SGR. The present study revealed that PER increased in supplemented diets while feed conversion ratio decreased. Feed efficiency (FE and PER) ratios are used as quality indicators for fish diet. So, these parameters are used to assess protein utilization and turnover. The results of the present study are also in agreement with those obtained by Khattab et al. (2004) who found that the dietary of Biogen increased feed intake, FCR, PER and body composition (crude protein, ether extract, ash and moisture) in fish. In this study, the results showed that body composition of $O$. niloticus, crude protein and ash increased significantly with diets containing different forms of ginger while total lipid content decreased significantly with the same forms of ginger. These results are similar to the finding of Abdelhamid et al. (2002) and Khattab et al. (2004) who concluded that inclusion of Biogen in the diet increased fish protein content and decreased whole body fat in fish. Ginger extracts are insulintropic 
rather than hypoglycemic and had better anti-diabetic effects. Much better antidiabetic effects of ginger and garlic may be obtained when feeding with a normal rather than a high fat-containing diet (Islam and Choi,2008; Mudoi et al. 2008).

Results of this study showed that, serum AST and ALT activities decreased significantly in the fish group fed on any form of ginger. These data agree with those reported by (Yemitan and Izegbu, 2006; Zhou et al.,2006, Jazet et al., 2008).who reported that oral administration of the volatile oil of ginger improved serum alanine aminotransferase ALT, aspartate aminotransferase AST; and alkaline phosphatase ALP levels, and influences both cell-mediated immune response and nonspecific proliferation of $\mathrm{T}$ lymphocyte, and may exert beneficial effects in chronic inflammation and autoimmune diseases. Similarly, ALT, AST; and ALP levels, improved significantly in rats treated with a mixture of garlic, ginger, vitamin E. (Nwanjo, and Oze, 2007).

The results obtained in this work showed that hepatic indices improved for fish fed the ginger diets, which are in agreement with those reported by Ajith et al. (2007) who evaluated hepatoprotective activity of aqueous ethanol extract of ginger (Zingiber officinale) against acetaminophen-induced acute hepatotoxicity in rat and found that aqueous extract of $Z$. officinale significantly protected the hepatotoxicity as evident from the activities of serum transaminase and alkaline phosphatase (ALP). Serum glutamate pyruvate transaminase (SGPT), serum glutamate oxaloacetate transaminase (SGOT) and ALP activities were significantly lowered in the treated animals. Hepatic lipid peroxidation was enhanced significantly in the control group. Administration of single dose of aqueous extract of ginger (200 and $400 \mathrm{mg} / \mathrm{kg}$,) significantly declines the activities of serum transaminases and ALP. Further the hepatic antioxidant status was enhanced in the ginger treated animals (Ajith et al., 2007).

The present findings revealed that glucose cholesterol and triglycerides levels in blood reduced significantly in fish fed on diets containing two forms of ginger. This condition was attributed to improving of the antioxidant system in $B$ cell of pancreas to produce insulin. Reduction of total lipid in blood serum of $O$. niloticun fed on diets containing ginger is agreement with the study of Al-Amin et al. (2006) who verified that serum total lipid and total cholesterol decreased significantly in men treated with ginger. Also, (Hussein et al., 2001), found that the serum total lipid decreased significantly in albino rats after administration of garlic. The activity of ALP in blood serum showed high significant decrease in fish groups fed on diets contained garlic as compared with the control group. These results are similar to results reported by (Metwally, 2009) ALP activity in Nile tilapia and catfish fed on antioxidant vitamin $\mathrm{C}$ and selenium was significantly decrease after exposure to copper toxicity compared to the control group, that at a dose of $500 \mathrm{mg} / \mathrm{kg}$, raw ginger was significantly effective in lowering serum glucose, cholesterol and triacylglycerol levels in the gingertreated diabetic rats compared with the control diabetic rats.. In addition, the 
ginger (Zingiber officinale) treated diabetic rats sustained their initial weights during the treatment period. The present data indicate that raw ginger possesses hypoglycemic, hypocholesterolaemic and hypolipidaemic potential, when Nile tilapia fingerlings fed on $2.0 \mathrm{mg} / \mathrm{kg}$ ginger dried rhizomes; $0.5 \mathrm{mg} / \mathrm{kg}$ ginger oil extract or $1.25 \mathrm{mg} / \mathrm{kg}$ mixture. Similarly, lower levels of plasma glucose in fish have also been reported in the assessment of biochemical effects of ginger findings in the experimental animal study by Ojewole (2006) who recorded that ginger dried rhizomes ethanol extract $(50-800 \mathrm{mg} / \mathrm{kg})$ possesses hypoglycemic properties. Total protein, globulin and albumins in plasma was significantly higher with the fingerlings tilapia fed on diet containing any form of ginger than the diets free from ginger (control), these results agrees with the results of Hussein, et al. (2001) who reported that serum total protein level was elevated in male albino rats after administration of garlic oil. Increase the total protein level in hyperlipidemic rats treated with garlic oil could be attributed to the increase in the immunoglobulin level and total globulin concentration .High blood protein levels have been reported due to improve liver and other organs functions which synthesized plasma protein.

The present study cleared that the gonadosomatic index improved significantly for male or female tilapia fingerlings fed the ginger supplemented diets as compared to the control groups, these results are similar to those recorded by Amin and Hamza (2006) who noted that Z. officinale treatment increased the activities of testicular antioxidant enzymes and restored sperm motility of treated rats.

Best survival rate were obtained in the present findings detected in fish groups fed on diets supplemented with ginger, these findings are in agreement with Adithepchaikarn et al. (2008), who reported that, fish diets containing either dry leaf powder or dried ethanol extract of $P$. guajava reduced mortality of A. hydrophila infected tilapia with no detected adverse effect on the fish. Similar trend was found, in this respect Guojun Yin et al. (2009) recorded that the best survival was in fish vaccinated group fed with both herbs Chinese herbs (Astragalus radix and Ganoderma lucidum), while almost 90\% of control fish vaccinated without herbs died. Also, in agreement with Nwanjo and Oze (2007) who found that, the supplementation of garlic led to $100 \%$ survival rate.

\section{CONCLUSION}

From the previous results, it could be concluded that adding of ginger (Zingiber officinale) to the diet on growth performance of fingerlings Nile tilapia (Oreochromis niloticus) showed positive effects. From growth parameters, feed utilization, body composition, liver and blood measurements data, all these results revealed that the feeding with a mixture of ginger (powder and oil extract), can enhance the growth rate remarkably, lower mortality rate and improve the physiological activities in cultured fish, and can be potentially used as good sources of antioxidants. Ginger supplements also maintain the 
efficiency of the components of the diet throughout the storage periods. It is necessary to increased research effort with regard to developing the use of these herbs, to investigate the effect of this plant scientifically, which have been used as traditional additives in fish diets to improve the quality of fish healthcare. More studies are required in animals on the use of ginger as dietary supplement in animal diets.

\section{REFERENCES}

Abdelhamid, A. M.; Khalil, F. F. M.; El-Barbary, M. I.; Zaki, V. H. and Husien, H. S. (2002). Feeding Nile tilapia Biogen to detoxify aflatoxin diets. In Proceeding of the $1^{\text {st }}$ Annual Scientific Conference of Animal and Fish Prod. Mansoura. pp 208-230.

Abegaz, B.; Asfaw, N. and Lwande, W. (1994).Chemical Constituents of the Essential Oil of Aframomum corrorima from Ethiopia, SINET: Ethiop. J. Sci., 17: 145-148.

Abou-zeid, S.M. (2002). The effect of some medical plant on reproductive and productive performance of Nile tilapia fish. Ph.D.Cairo Univ., Fac.of Agricult. 212pp.

Adegoke, G. O. and Skura, B.G. (1994). Nutritional profile and antimicrobial spectrum of the spice A. danielli. shum. Plant Foods Human Nutrit. 45: 75-182.

Adegoke, G.O.; and Gopalakrishna, A.C. (1998). Extraction and Identification of antioxidants from the spice Aframomum danielli, J. Am. Oil Chem. Soc. 75: 1047-1052.

Adegoke, G.O.; Fasoyiro, S. B. and Skura, B. (2000). Control of micro-bial growth, browning and lipid oxidation by the spice Aframomum danielli. European Food Research Technology 211: 342-345.

Adegoke, G.O.; Makinde, O.; Kolowaole, O.F. and Uzo-Peters, P.I. (2003). Extraction and characterization of antioxidants from Aframomum melegueta and Xylopia aethiopica. Eur. Food Res. Technol. 216: 526528. 
Adegoke, G.O.; Falade, K.O. and Babalola, O.C. (2004). Control of lipid oxidation and fungal spoilage of roasted peanut (Arachis hypogea) using the spice Aframomum danielli Food, Agriculture \& Environment 2 (1): 128-131.

Adithepchaikarn Pachanawan Parichat Phumkhachorn and Pongsak Rattanachaikunsopon (2008). Potential of Psidium guajava Supplemented Fish Diets in Controlling Aeromonas hydrophila Infection in Tilapia (Oreochromis niloticus). J. of Biosc. and Bioengin. 106:(5) 419-424.

Ahmed, R.S.; Seth, V. and Banerjee, B.D. (2000). Influence of dietary ginger (Zingiber officinales Roscoe) on antioxidant defense system in rat: comparison with ascorbic acid. Indian J Exp Biol. 38(6):604-6.

Ajith, T.A.; Hema, U. and Aswathy, M.S., (2007). Zingiber officinale Roscoe prevents acetaminophen-induced hepatotoxicity by enhancing hepatic antioxidant status. Food Chem Toxicol., 11:2267-2272.

Al-Amin, Z,M.; Thomson, M.; Al-Qattan, K.K.; Peltonen-Shalaby, R.and Ali, M. (2006). Anti-diabetic and hypolipidaemic properties of ginger (Zingiber officinale) in streptozotocin-induced diabetic rats. Br J Nutr. 96(4): 660-676.

Alexander, R.R.; Griffiths, J. and Wilkinson, M. L. (1985).Basic Biochemical methods. John Wiley \& Sons, Inc. 3:154-157.

Ali, B.H.; Blunden, G.; Tanira, M.O. and Nemmar, A. (2008). Some phytochemical, pharmacological and toxicological properties of ginger (Zingiber officinale Roscoe): a review of recent research. Food Chem Toxicol. 46(2):409-20.

Amin A, Hamza AA. (2006). Effects of Roselle and ginger (Zingiber officinale) on cisplatin-induced reproductive toxicity in rats. Asian J Androl. , (5):607-12.

AOAC: (1995). Association of Official Analytical Chemists, Official methods of analysis. 16th edition, AOAC, Arlington, VA. 1832pp. 
Armstrong, W. D. and Carr, C. W. (1964).Physiological chemistry laboratory directions. ( $3^{\text {rd }}$ ed.). Burges Publishing Co., Minneapolis, Minnesota.

Bhandari, U.; Kanojia, R. and Pillai, K.K. (2005). Effect of ethanolic extract of Zingiber officinale on dyslipidaemia in diabetic rats. J Ethnopharmacol. 97(2):227-30.

Boyd, C.E. (1990). Water quality in ponds for aquaculture. Birmingham Publishing Co.,Birmingham, Alabama, USA. 482 pp.

Chang, S. S.; Ostric-Matjasevic, B.; Hsieh, O. A. C. and Huang, C. (1977). Natural antioxidants from rosemary and sage. Journal of Food Science 42: 1102-1106.

Coulter, R. B. 1988. Extending shelf life by using traditional phe-nolic antioxidants, Cereal Foods World, 33:207-210.

Doumas, B. T.; Waston, W. and Biggs, H. H. (1977). Albumin standards and the measurements of Serum albumin with Bromocresol Green. Clinical Chemistry Acta 31: 87-96.

Duncan, D.B. (1955). Multiple range and multiple $\mathrm{F}$ tests. Biometrics, 11(1): 42-29.

Economou, K. O.; Oreopoulou, V. and Thomopoulos, C. D. (1991). Antioxidant activity of some plant extracts of the family Labitae. Journal American Oil Chemists Society 68(2):109.

Eyob S, Appelgren M, Rohloff J, Tsegaye A, Messele G., (2008). Traditional medicinal uses and essential oil composition of leaves and rhizomes of korarima (Aframomum corrorima (Braun) P.C.M. Jansen) from southern Ethiopia. S. Afr. J. Bot. 74: 181185.

Giese, J.(1996). Antioxidants: Tools for preventing lipid oxidation. Food Technology Nov: 73 -78.

Gornall,A.G.; Bardawill, C.L. and David, M. M. (1949). Determination of serum proteins by mean of the biuret reagent. J. Biol. Chem., 177: $751 \mathrm{pp}$. 
Goyal, RK.; Kadnur SV. Kadnur. (2006). Beneficial effects of Zingiber officinale on gold thioglucose induced obesity. Fitoterapia. 77 (3): 160-163.

Guojun, Yin, L.; Ardo, K.D.; Thompson, A.; Adams, Z.; Jeney, and Jeney, G. (2009). Chinese herbs enhance immune response of carp, Cyprinus carpio, and protection against Aeromonas hydrophila Fish \& Shellfish Immunology, 26(1): 140-145.

Handel, E.V. (1965).Estimation of glycogen in small amount of tissue Ana.Biochem., 11: 256-265.

Huguette, A.; Chantal, M.and Bessiere, J-M. (2004). Aromatic plants of tropical central Africa. Chemical composition of essential oils of the leaf and rhizome of Aframomum giganteum K. Schum fromGabon. Flav. Fragr. J. 19: 205-209.

Hussein, S.A.; Abd-El-Maksoud, H. and Azab, M.E. (2001). Certain biochemical effect of garlic oil on normal and experimentally induced hyperlipidemia in male albino rats. International Scientific Conference 2, Mansoura Univ., 1: 103-129.

Islam, MS. and Choi, H. (2008). Comparative effects of dietary ginger (Zingiber officinale) and garlic (Allium sativum) investigated in a type 2 diabetes model of rats. J Med. Food., 1:152-9.

Ivan, A. R. (2005), Medicinal plants of the world: chemical constituents, traditional and modern medicinal uses, Totowa, N J: Humana Press, 3: 507-543., $648 \mathrm{pp}$.

Jazet Dongmo, P.M.; Fekam Boyom, F.; Sameza, M.L.; Kwazou, N.L. and Amvam Zollo, C.; (2008). Investigations on the essential oils of some Aframomum species (Zingiberaceae) from Cameron as potential antioxidant and anti-inflammatory agents Int. J. of Essential Oil Therap., 2.149-155.

Kan He, Zhongguang Shao, Naisheng Bai, Tangsheng Peng, Marc Roller, Qunyi Zheng (2008). A New Process for Sterilization and Disinfecting of Agricultural and Botanical Herbal Products American Chemical Society Symposium Series, Vol. 987:264-280. 
Karamjit, K. (2007). Evaluation of the potential use of ginger as a fruit preservatives Society for Advancement of Chicanos/Latinos and Native Americans in Science 2007 SACNAS National Conference Kansas City, Missouri October 11-14, 2007.

Kerdchoechuen O. (2007). Antibacterial effect of five Zingiberaceae essential oils Molecules.12(8):2047-60.

Khanam, S.; Deep, M. and Shivanand, A. (2006). Antioxidant activity of a new diarylheptanoid from Zingiber officinale. Pharmacog Mag, 2(8): 254-257.

Khattab, Y. A. E.; Shalaby, A. M. E.; Sharaf Saffa, M.; El-Marakby, H. and RizlAlla, E. H. (2004). The physiological changes and growth performance of the Nile Tilapia Oreochromis niloticus after feeding with Biogen as growth promoter. Egypt. J. Aquat. Biol. And Fish. 8: (2): 145-158.

Kim, JS.; Lee, SI.; Park, HW.; Yang, JH.; Shin, TY.; Kim, YC.; Baek, NI.; Kim, SH.; Choi, SU.; Kwon, BM.; Leem, KH.; Jung, MY. and Kim, DK. (2008). Cytotoxic components from the dried rhizomes of Zingiber officinale Roscoe. Arch Pharm Res. 31(4):415-8.

Leung, A. and Foster, S. (1996). Encyclopedia of Common Natural Ingredients Used in Foods, Drug and Cosmetics. 2nd. ed. New York: John Wiley $\&$ Sons.

Metwally, M.A.A. (2009). Effects of Garlic (Allium sativum) on Some Antioxidant Activities in Tilapia Nilotica (Oreochromis niloticus) World Journal of Fish and Marine Sciences 1(1): 56-64

Mudoi, T.; Sarmah, R.N.; Baishya, S.; Borah, R.C.; Saikia, S. and Das, P. (2008). The Effect of Ginger (Zingiber officinale Roscoe) Waste Meal on Growth Performance, Carcass Characteristics, Serum Lipid and Serum Cholesterol Profiles of Rabbit.Genetic diversity in Ginger (Zingiber officinale Rosc.) Spice India, 21(8): 24-28.

Natarajan, KS.; Narasimhan, M.; Shanmugasundaram, KR. and Shanmugasundaram, ER. (2006). Antioxidant activity of a salt-spice- 
herbal mixture against free radical induction. J Ethnopharmacol., 105 (1-2):76-83.

Nedyalka V. Yanishlieva and Emma M. Marinova (2001). Stabilisation of edible oils with naturalAntioxidants Eur. J. Lipid Sci. Technol. 103: 752-767

Nicoll, R. and Henein, MY. (2009). Ginger (Zingiber officinale Roscoe): a hot remedy for cardiovascular disease? Int J Cardiol. 131(3):408-9.

NRC .(1993). Nutrient requirement of fish. National Academy Press, Washington DC

Nwanjo, H.U. and G.O. Oze, (2007). Changes in Serum Lipid Profiles and Heart Rate in Rats Treated With Aqueous Garlic Extract. J. Nutr. Wellness, 4: 1 pp.

Odukoya, A. Olukemi; Ilori, O. Olukemi; Sofidiya, M. Oluwatoyin; Aniunoh, O. Austin; Lawal, B. Mansuratand and Tade, I. Olufunmilola (2005). AntioxidentActivity of nigerian dietry spices Electron. J. Environ. Agric. Food Chem., 4 (6):1086-1093.

Ojewole JA. (2006).Analgesic, antiinflammatory and hypoglycaemic effects of ethanol extract of Zingiber officinale (Roscoe) rhizomes (Zingiberaceae) in mice and rats. Phytother Res. 9:764-72.

Oliveira CH.; Moraes ME.; Moraes, MO.; Bezerra, FA.; Abib, E. and De Nucci G. (2005). Clinical toxicology study of an herbal medicinal extract of Paullinia cupana, Trichilia catigua, Ptychopetalum olacoides and Zingiber officinale (Catuama) in healthy volunteers. Phytother Res. 19(1):547.

Pokorny, J. (1991). Natural Antioxidants for Food Use. Trends Food Sci. Technol. 2: 223-227.

Rettman, S. and Frankel, S. (1975). Colorimetric determination of glutamic oxaloacetic and glutamic pyruvic transaminase. J. Clin. Pathol. 28-56 pp. 
SAS Institute, (2002). SAS software version 8. SAS Institute Inc., Cary, North Carolina. USA.

Sob, S. T.; Tane, P.; Ngadjui,B. T.; Connoly, J. D. and Ma, D. (2007). Trypanocidal diterpenoids from the seeds of Aframomum aulacocarpos (Zingiberaceae).Tetrahedron,63: 8993-98

Stein, E.A. (1986), Text book of clinical chemistry N.W. Tietz (Ed.) W. B. Saunders Co. Philadelphia : 1818-1829pp.

Tao QF.; Xu Y.; Lam RY.; Schneider B.; Dou H.; Leung PS.; Shi SY.; Zhou, CX.; Yang LX.; Zhang RP.; Xiao YC.; Wu X.; Zeng S.; Cheng CH. and Zhao Y. (2008).Diarylheptanoids and a monoterpenoid from the rhizomes of Zingiber officinale: antioxidant and cytoprotective properties. J. Nat Prod. 71(1):127.

Trinder, P. (1969). Determination of glucose in blood using glucose oxidase with an alternative oxygen acceptor. Annual Clin. Biochem., 6: 24-27.

Williamson, E. (2003). Potter's Herbal Cyclopaedia London: C.W. Daniel.

Yemitan, OK. and Izegbu, MC. (2006). Protective effects of Zingiber officinale (Zingiberaceae)against carbon tetrachloride and acetaminophen-induced hepatotoxicity in rats. Phytother Res. 20(11):997-1002.

Zhou, HL.; Deng, YM. and Xie, QM. (2006).The modulatory effects of the volatile oil of ginger on the cellular immune response in vitro and in vivo in mice. J Ethnopharmacol. 105(1-2):301-5.

Zollner, N. and Kirsch, K. (1962). Uber die quantitative Bestiming von lipoiden (Micromethod) mittles der vielen naturlichen lipoiden (allen bekannten plasma lipoiden) gemeinsamen sulfophosphovanillin-reaktion. Z. ges. Exp. Med., 135: 545-561. 